УДК 621.354:662.43

(C) 2012

Дмитриков В. П., доктор технічних наук,

Падалка В. В., кандидат технічних наук

Полтавська державна аграрна академія

Проценко О. В., кандидат хімічних наук, Коломєєц В. І., викладач

Дніпродзержинський державний технічний університет

\title{
ТЕХНОЛОГІЯ ПЕРЕРОБКИ ВІДПРАЦЬОВАНИХ СВИНЦЕВО-ЦИНКОВИХ ГАЛЬВАНІЧНИХ ЕЛЕМЕНТІВ
}

\author{
ПОВІДОМЛЕННЯ 2. ТЕХНОЛОГІЧНА СХЕМА ПЕРЕРОБКИ
}

\section{Рецензент - доктор сільськогосподарських наук, професор П. В. Писаренко}

\begin{abstract}
За результатами лабораторних досліджень технологій переробки відпрацьованих свинцевоцинкових гальванічних елементів і акумуляторів запропоновано екологічно безпечну схему їх утилізачії. Наведено стадї досліджених хімічних процесів і результати їх перетворень, щчо відбуваються за комплексної переробки відпрацьованих акумуляторів. Запропоновано вдосконалену методологію і схему технологічного процесу утилізації свинцево-иинкових джерел струму з використанням існуючого та стандартного устаткування для процесів переробки з використанням хімічних реатентів.
\end{abstract}

Ключові слова: машини, гальванічні елементи, екологія, технологія переробки, метали, утилізаиія.

Постановка проблеми. Найважливішою частиною технологічного проектування всього підприємства, основних і допоміжних виробничих цехів й установок $є$ створення технологічної схеми, що відображає взаємозв'язок і характер окремих технологічних процесів і устаткування. Як проектний документ технологічна схема $є$ графічним зображенням сукупності операцій, що утворюють закінчений технологічний процес, i супроводжується описом i необхідними розрахунками (розрахунково-пояснювальною запискою) [6].

Специфіка хіміко-механічної поведінки відпрацьованих джерел струму визначає склад i структуру технологічної схеми їх переробки.

Технічний рівень і якість технологічної схеми визначаються детальним опрацьовуванням окремих технологічних вузлів заздалегідь окресленої принципової схеми [4]. Технологічним вузлом зазвичай називають апарат (споруду, машину) або їх групу, в яких починається й повністю закінчується один з етапних процесів, необхідних для досягнення заданого ступеня переробки початкового матеріалу, зокрема вторинного матеріалу для спеціалізованих підприємств, цехів або установок переробки відходів.

Аналіз останніх досліджень та публікацій, у яких започатковано розв'язання проблеми. Раніше [3] були конкретизовані головні напрями утилізації відпрацьованих свинцево-цинкових гальванічних елементів і акумуляторів (загальна назва АКБ).

Із метою вибору оптимального варіанта утилізації відпрацьованих АКБ доцільно використовувати інформаційно-пошукову та інформаційно-аналітичну системи; за необхідності підключають експертну систему й математичне моделювання [2].

Хімічні перетворення і фізико-технічні процеси, що їх супроводжують, вивчали на подрібненому акумуляторному ломі в умовах $[1,5]$. Відпрацювання технології переробки АКБ виконували на основі лабораторних досліджень, враховуючи особливості їх протікання, котрі конкретизовані у таблиці.

Мета та завдання досліджень. Створення технології переробки відпрацьованих свинцевоцинкових гальванічних елементів і акумуляторів.

Для вирішення мети необхідно розробити технологічну схему переробки та повної утилізації відпрацьованих АКБ.

Результати досліджень. На основі проведених досліджень розроблена схема хімічних перетворень АКБ (рис. 1) і технологічна схема утилізації відпрацьованих АКБ (рис. 2). 
ТЕХНІЧНI НАУКИ

Етапи і хімізм процесу переробки АКБ

\begin{tabular}{|c|c|}
\hline Стадії процесів & Результати \\
\hline $\begin{array}{l}\text { Розчинення цинку та оксиду свинцю (IV) в сірчаній } \\
\text { кислоті, відновлення свинцю (IV) в свинець (II) }\end{array}$ & $\begin{array}{c}\mathrm{Zn}+\mathrm{H}_{2} \mathrm{SO}_{4}=\mathrm{ZnSO}_{4}+\mathrm{H}_{2} \\
\mathrm{PbO}_{2}+2 \mathrm{H}_{2} \mathrm{SO}_{4}=\mathrm{Pb}\left(\mathrm{SO}_{4}\right)_{2}+2 \mathrm{H}_{2} \mathrm{O} \\
\mathrm{Pb}^{4+}+\mathrm{H}_{2}=\mathrm{Pb}^{2+}+2 \mathrm{H}^{+} \\
\mathrm{PbO}_{2}+\mathrm{H}_{2} \mathrm{SO}_{4}=\mathrm{PbSO}_{4}+\mathrm{H}_{2} \mathrm{O}+0,5 \mathrm{O}_{2}\end{array}$ \\
\hline Фільтрування сульфатів свинцю і цинку & Осад $\mathrm{PbSO}_{4}$, розчин $\mathrm{ZnSO}_{4}$ \\
\hline Одержання карбонату свинцю & $\mathrm{PbSO}_{4} \downarrow+\mathrm{Na}_{2} \mathrm{CO}_{3}=\mathrm{PbCO}_{3} \downarrow+\mathrm{Na}_{2} \mathrm{SO}_{4}$ \\
\hline $\begin{array}{c}\text { Вимивання водою сульфату натрію } \\
\text { з суміші з карбонатом свинцю }\end{array}$ & Осад $\mathrm{PbCO}_{3}$, розчин $\mathrm{Na}_{2} \mathrm{SO}_{4}$ \\
\hline Фільтрування розчину з осадом карбонату свинцю & Осад $\mathrm{PbCO}_{3}$ \\
\hline Сушка і прожарювання осаду карбонату свинцю & $\mathrm{PbO}, \mathrm{CO}_{2}$ \\
\hline $\begin{array}{c}\text { Відновлення оксиду свинцю (II) воднем } \\
\text { у вільний свинець } \\
\end{array}$ & $\mathrm{PbO}+\mathrm{H}_{2}=\mathrm{Pb}+\mathrm{H}_{2} \mathrm{O}$ \\
\hline Осадження сульфату цинку гідроксидом натрію & Осад $\mathrm{Zn}(\mathrm{OH})_{2}$, розчин $\mathrm{Na}_{2} \mathrm{SO}_{4}$ \\
\hline Фільтрування розчину з осадом гідроксиду цинку & Осад $\mathrm{Zn}(\mathrm{OH})_{2}$ \\
\hline Сушка і прожарювання осаду гідроксиду цинку & $\mathrm{ZnO}, \mathrm{H}_{2} \mathrm{O}$ \\
\hline Відновлення оксиду цинку воднем & $\mathrm{Zn}, \mathrm{H}_{2} \mathrm{O}$ \\
\hline $\begin{array}{c}\text { Випаровування, кристалізація й сушка } \\
\text { розчину сульфату натрію }\end{array}$ & Кристалічний $\mathrm{Na}_{2} \mathrm{SO}_{4}, \mathrm{H}_{2} \mathrm{O}$ \\
\hline
\end{tabular}

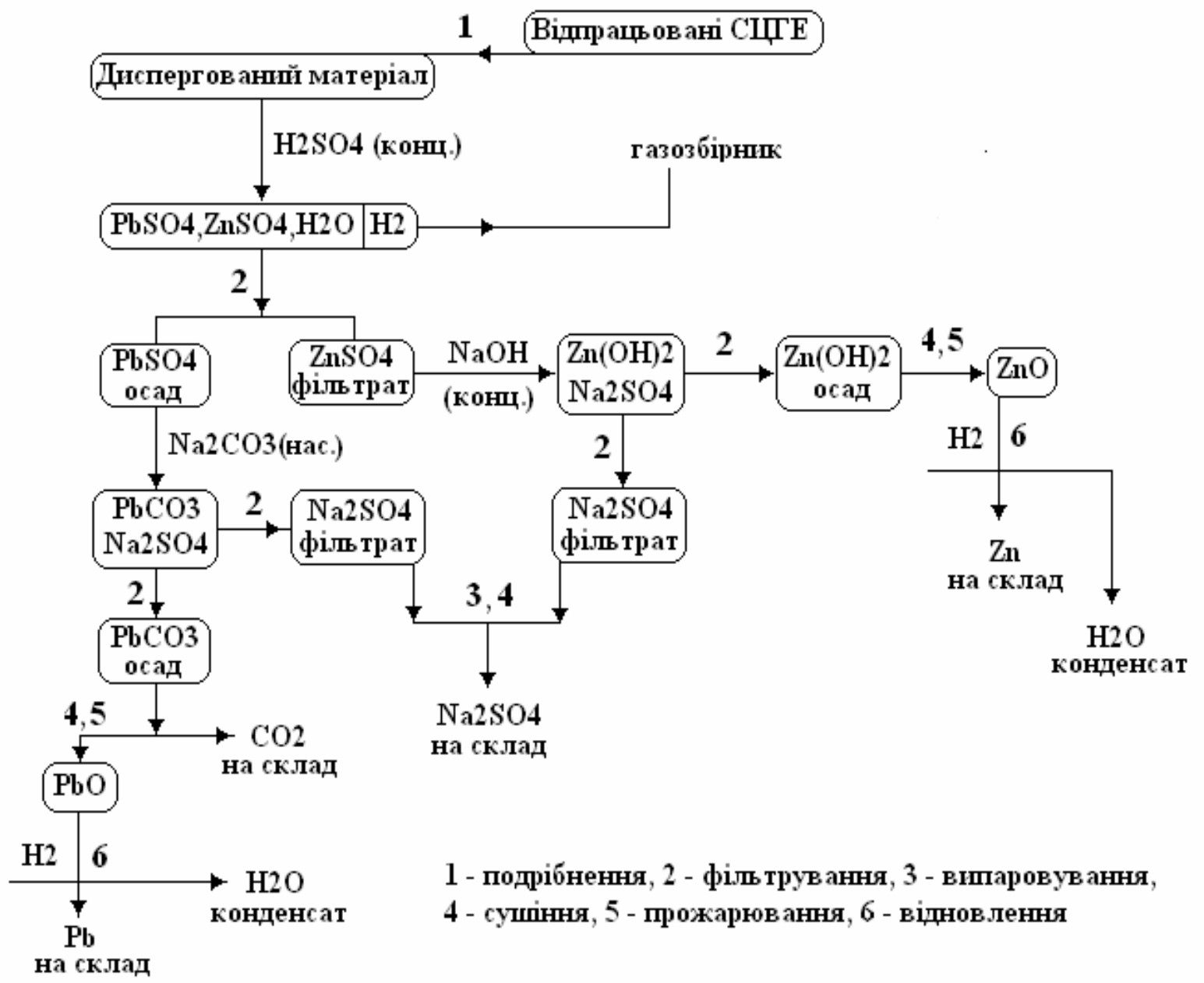

Рис. 1. Схема хімічних перетворень при утилізації АКБ 
Синтез технологічних схем на основі різноманіття варіантів різних технологічних вузлів проводиться, наприклад, методом динамічного програмування - крокового ухвалення рішень за визначенням оптимального варіанта на основі вибраного критерію оптимальності (мінімуму загальних витрат або максимуму економічного результату, що враховує величину запобіжного збитку навколишньому середовищу або значення плати за дозволене скидання). Важливу роль у цьому відіграють певні евристичні правила (рекомендаціі).

За безперервного процесу забезпечується отримання якіснішої продукції й утворюється порівняно менша кількість відходів, знижуються також втрати сировини і матеріалів. Устаткування для безперервних процесів зазвичай відрізняється більшою продуктивністю. Крім того, безперервні процеси відносно легко піддаються ме- ханізації й автоматизації. Їх застосування найраціональніше у виробництвах великої потужності. В окремих випадках у періодичну схему включають безперервно працюючі технологічні вузли (ректифікації, екстракції, сушки і т. д.)

Із бункера 1 АКБ поступають на вальцову дробарку 2, а диспергований матеріал збирається в бункері-живильнику, звідки конвеєром 4 подається в завантажувальний бункер 5. Із бункера 5 подрібнений матеріал поступає в реактор 6 , котрий містить сірчану кислоту, що подана 3 ємкості 7 через дозатор 8.

Реактор 6 обладнаний механічною мішалкою; цинк і оксид свинцю (IV) розчиняються у сірчаній кислоті 3 відновленням свинцю (IV) в свинець (II). Надлишок водню через краплевідбійник 9 і холодильник 10 потрапляє в газозбірник 11.

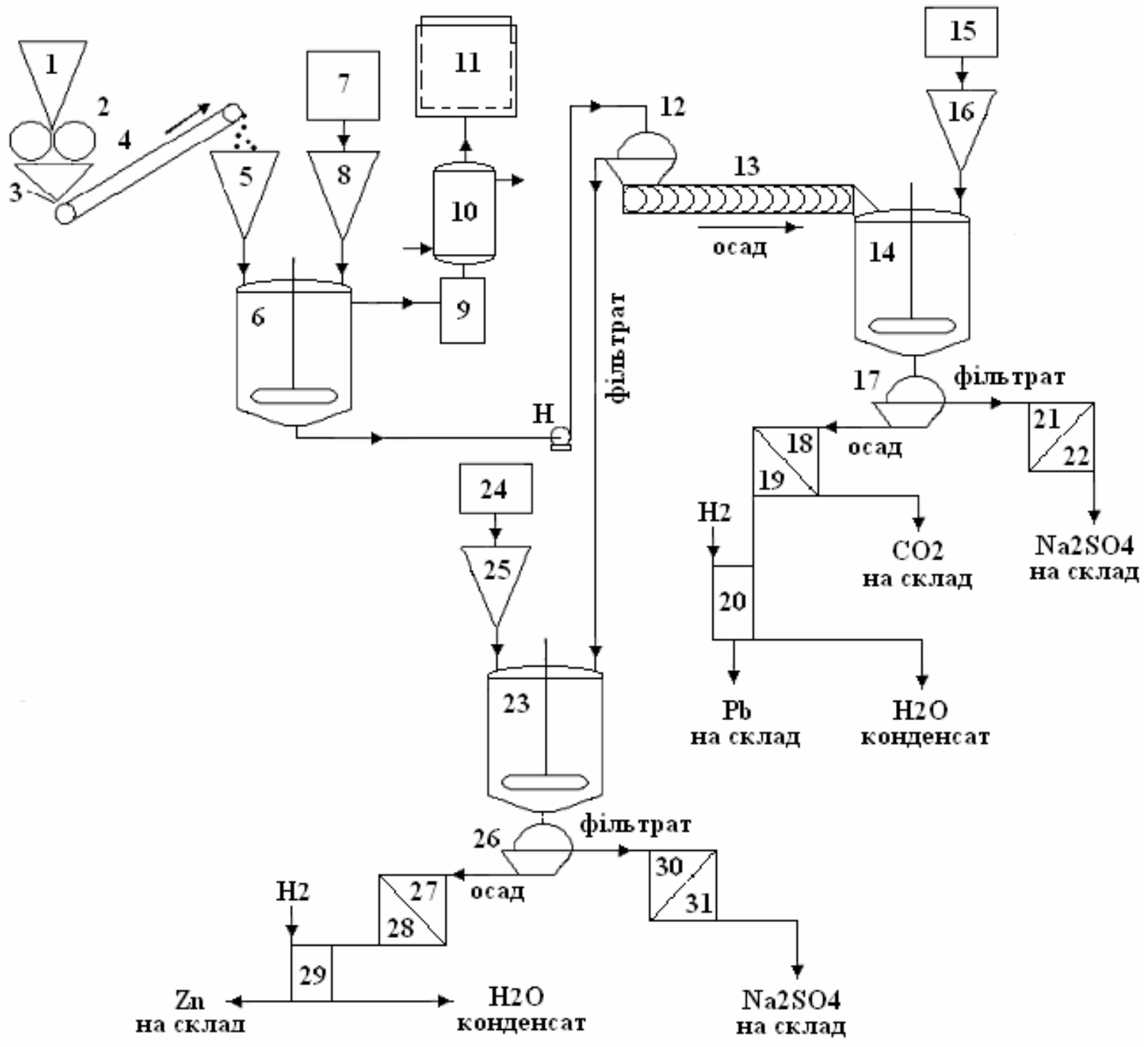

Рис. 2. Схема технології утилізації відпрацьованих АКБ 
Насос Н подає пульпу з реактора 6 на механічний фільтр 12 , де пульпу розділяють на осад i фільтрат. Осад сульфату свинцю після фільтру 12 подає шнек 13 у реактор 14, обладнаний механічною мішалкою. Для перетворення сульфату свинцю на карбонат у реактор поступає насичений розчин карбонату натрію з ємкості 15 через дозатор 16. Пульпа 3 реактора 14 потрапляє на механічний фільтр 17 , де пульпу розділяють на осад і фільтрат.

Осад карбонату свинцю після фільтра 17 у результаті сушки в сушарці 18 і прожарювання в термокамері 19 перетворюють на оксид свинцю (II) і оксид вуглецю (IV), що поступає на склад. Оксид свинцю (II) відновлюють у печі 20 в металевий свинець, який поступає на склад, а водяна пара утворює конденсат. Після фільтра 17 розчин сульфату натрію упарюють у випарці 21 i сушать у сушарці 22, після чого сульфат натрію у вигляді кристалогідрату подають на склад. Після фільтра 12 фільтрат (розчин сульфату цинку) подають у реактор 23, обладнаний механічною мішалкою.

Для перетворення сульфату цинку на гідроксид у реактор подають концентрований розчин гідроксиду натрію з ємкості 24 через дозатор 25, а суміш осаду гідроксиду цинку і розчину сульфату натрію, що утворилася, поступає на фільтр 26. Фільтрат (розчин сульфату цинку) після фільтру 26 подають у випарку 30 і сушарку 31 й

\section{БІБЛІОГРАФІЯ}

1. Баранов А. А. Технология вторичных цветных металлов и сплавов. / А. А. Баранов, О. М. Микуляк, А. А. Резняков, - К. : Вища школа. - 1988. $-163 \mathrm{c}$.

2. Дмитриков В. П. Нечеткости определений экспертной системы мониторинга химических загрязнителей // Вестник НТУ «ХПИ». - 2004. №38. - C. 17-20.

3. Дмитриков В. П. Технологія переробки відпрацьованих свинцево-цинкових гальванічних елементів. Повідомлення 1. Принципи переробки хімічні реакції / В. П. Дмитриков, Р. М. Харак, О. В. Проценко, В. І. Коломєєц // Вісник далі - на склад у вигляді кристалогідрату натрію.

Після фільтра 26 осад гідроксиду цинку подають у сушарку 27 і термокамеру 28 для отримання сухого гідроксиду цинку. Після відновлення оксиду цинку у відновлювальній печі металевий цинк поступає на склад, а водяна пара утворює конденсат. Усі конденсати водяної пари використовують у приготуванні розчинів реагентів для технологічного процесу.

Запропонований спосіб дозволяє повернути в сферу виробництва компоненти АКБ у вигляді товарних продуктів: свинець і цинк - для електротехнічної промисловості; сполуки свинцю і цинку - сировини для гальванічної і металургійної промисловості, сульфат натрію - для скляної промисловості, водень і вуглекислий газ - для хімічної та металургійної промисловості, знесолену воду - для технічних цілей.

\section{Висновки:}

1. Наведено результати досліджень реагентної переробки відпрацьованих свинцево-цинкових джерел струму. Запропоновано вдосконалену методологію й технологію переробки АКБ.

2. Технологія $\epsilon$ енергоресурсозберігаючою, екологічно безпечною й практично безвідходною. Головні елементи технологічної схеми побудовані з використанням стандартного устаткування. Продукти переробки АКБ доцільно рекомендувати для утилізації у сфері виробництва та використання в різних галузях промисловості.

Полтавської державної аграрної академії. - 2011. - №4. - С. 147-150.

4. Дытнерский Ю. И. Процессы и аппараты химической технологии. В 2-х кн.: Часть 1. Теоретические основы процессов химической технологии. Гидромеханические и тепловые процессы и аппараты. - М. : Химия. $-1995 .-400$ с.

5. Технология вторичных цветных металлов / И. Ф. Худяков, А. П. Дорошкевич, Э. Кляйн [и др.]. - М. : Металлургия. $-1981 .-280$ с.

6. Chemical and Process Design Handbook / James G. Speight. - New York etc.: McGraw-Hill. - 2002. $-1029 \mathrm{p}$. 